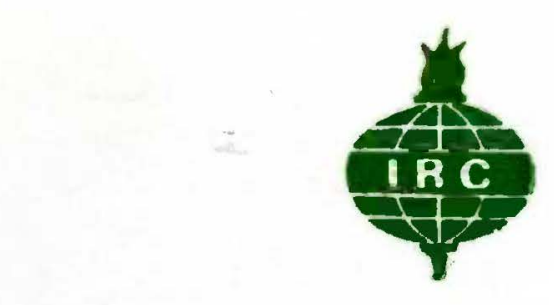

\title{
INTERNATIONAL
}

\section{RESCUE COMMITTEE}

\section{CITIZENS COMMISSION CONFERENCE \\ FEBRUARY 23 - 25, 1989 \\ ISLAMABAD}


SUMMARY OF IRC CONFERENCE CONCERNING THE SECOND REPORT OF

THE CITIZENS COMMISSION ON AFGHAN REFUGEES:

VISIT OF OCTOBER 10 - 19, 1988

CONFERENCE DATES: FEBRUARY $23-35,1989$ ISLAMABAD， PAKISTAN 
TABLE OF CONTENTS

Summary of IRC Conference

List of Appendices

Appendix A

Appendix B

Appendix C

Appendix D

14

Appendix E

18

Group 1

Group 2

Group 3

Group 4

Group 5

18

20

26

29

31

Appendix $\mathrm{F}$

36 
SUMMARY OF IRC CONFERENCE

CONCERNING THE

SECOND REPORT OF THE CITIZENS COMMISSION ON AFGHAN

REFUGEES: VISIT OF OCTOBER 10-19, 1988

On February 23 through February 25 IRC held a conference to discuss the findings of the Second Citizens Commission Report. The conference was held in Islamabad at the Holiday Inn.

This locale was selected for several reasons: it was felt that by having the conference in Is mabad, attendees would not be interrupted by daily demands; the Holiday Inn was the most efficient of the several hotels contacted in Islamabad and Rawalpindi in meeting the needs of a large conference; the Holiday Inn's prices were compatible with other hotels; and other areas such as Swat (which several people mentioned) are too cold at this time of year.

Over 80 IRC staff members were invited. All international staff were invited since most are managerial level; those that are not managers would benefit from the insights gained at the conference since they all work with Afghan staff. All managerial level Afghan and Pakistani staff were invited. In addition, other Afghan non-managerial level staff were invited who had worked with IRC for some time and who had special expertise that would contribute to the conference. Every staff member received a copy of the second Citizen's Commission Report with their invitation to attend.

In addition, all members of the ACBAR steering Committee were invited as well as the ACBAR Executive Coordinator and his Deputy. It would have been impossible to invite heads of all the agencies in Peshawar and it was felt that by inviting the steering Committee we had invited the agencies' representatives. Also invited were the ambassadors or their representatives from several embassies: France, the Netherlands, Sweden, Norway, Great Britain, United States, Canada and Germany. We also invited representatives from USAID, the world Food Programme, the UN Coordinator's office and the UN Development program. Copies of the second Citizen's Commission Report were available during the conference for all participants.

The conference schedule included an introductory session on Thursday, two sessions with small groups to discuss various issues (on Thursday and Friday), and a panel discussion on Friday morning with three representatives of international bodies: Larry CrandaII from USAID, Islamabad; Allen Jones from WFP, Islamabad; and Martin Barber from the UN Coordinator's Office, Islamabad. 
These representative were asked questions by three Afghans with extensive experience in Afghanistan relief work: Mr. Ghafoori, Director, German-Afghanistan Foundation; Dr. Haider, Swedish Committee; and Dr. Hassani, IRC Education Program.

The introductory session on Thursday morning started with a short introduction by steve Segal. He pointed out IRC's accomplishments during the time it has been assisting Afghan refugees. For example, IRC now employs about 1,300 people, of whom 858 are Afghans, and it has established extensive medical, public health, education, training and self-reliance programs in both Peshawar and the Hangu-Thal area. He attributed IRC's successes to four factors: its ability to listen to the ideas of others and accord respect to their views; support for the people working for IRC through building self-esteem and making people feel wanted and important; its flexibility in planning and willingness to accept and try new ideas; and a sense of humor and tolerance when dealing with others.

Tom Yates then spoke, pointing out that IRC is a refugee organization and as such has "no long-term future" in Afghanistan. Rather, it will assist Afghans in helping themselves, and programs will be turned over to them. IRC is a voluntary organization, not forced to provide assistance. It does not normally work through governments but rather through local communities. He asked that the conference participants think about IRC's future relationships with any government in Afghanistan and with the party alliance. He also asked that people consider what IRC's priorities should be for its future work in Afghanistan.

During Thursday afternoon the session broke up into five smaller groups to discuss IRC's plans for future work. An outline of these future plans and a format for the discussion groups (Appendix D) was distributed to all conference participants and formed the basis for the small groups' discussions.

On Thursday evening there was a speech by Anne Willam Bijleveld from UNHCR. He pointed out that a traditional repatriation approach will not work in Afghanistan but instead will depend on the refugees voluntary return. UNHCR is presently informationgathering on the conditions of various districts in Afghanistan to determine which will be vulnerable once refugees do return. In addition, they are monitoring present refugee movements. He pointed out that once refugees return to Afghanistan there will be no distinction made between refugees, internally displaced and those who stayed. The first priority will be agricultural production in order to assist the people of Afghanistan in becoming self-sufficient in food as soon as is possible. 
At other times during the conference, films were shown on management techniques, videotapes on different aspects of Afghanistan and its need for rehabilitation, and a concluding session on Saturday morning summarized the points made in the small groups.

The presentations by the group leaders on saturday morning summarized the discussions held by the five groups. The points covered a wide range of topics, most of which met the same concerns as the Second Citizen's Commission Report. In addition, the question and answer session provided more material for future planning.

Appendix $E$ are the notes of the Recorders for the small groups. The main points of the groups, made at the concluding session, can be summarized as follows.

Group 1 (chaired by Abdul Zahir Reja) pointed out that programs should be implemented through shuras, preferably district-level shuras, whose credibility in the community has been verified by IRC. Programs must be flexible and the shuras informed that IRC will not pay wages (the shura will be in control of this) and free food or free assistance should be avoided. IRC should not be doing development work, but rather rehabilitation and meeting basic needs. The shuras should form subcommittees to implement projects but the shura itself should set priorities. Payments to shuras should be made in installments and technical consultants should assist or control when difficulties are encountered. Mine awareness programs should be implemented with coordination between the NGOs and UN agencies. The refugees in Pakistan should be informed of IRC's schedule of work in various districts and it will be their decision whether to return to a district where IRC is working.

Group 2 (chaired by Aziz Osmani) felt there was a need for mine awareness integrated into all IRC programs, particularly education and health. They approved of working through the shuras because these can represent the community's interests. IRC should cease assistance to any shura if funds are misappropriated or for other valid reasons. They recommended that IRC's policy of temporary assistance be publicized and that shuras be instructed in various skills so that programs can be handed over to shuras as soon as possible. IRC should maintain good communications, management instruction, stay flexible, and adapt to a shura's way of doing things without trying to create new methods. They agreed that women should be encouraged to participate in shuras and that IRC should help shuras only if they represent the whole community, including women. They also felt it was important for English to be taught since it is the language of science, technical skills and communication with outsiders. They also believed that people going into Afghanistan should be familiar with its culture. 
Group 3 (chaired by Dr. Anwar) felt that purchasing back ration cards was unfair since there are so many unregistered refugees. They felt that professional training should be done in Pakistan so skills can be taken back into Afghanistan. IRC should work with shuras, but since they have no official structure, work should begin with pilot projects. While no conclusions were reached regarding the logistical problems of commodities distribution, they suggested that the same system be used that transferred arms into Afghanistan and that the market be used with careful monitoring. There was no consensus on how to control price variations in different regions. IRC's approach should be flexible and should try different types of programs, including an emphasis on food production, cash for work and market mechanisms. The role of women needs to be addressed. In addition, they wanted to know why IRC was limiting its work to Paktia/Paktika, Nangahar and Logar Provinces.

Group 4 (chaired by Dr. Hassani) felt that IRC should work with spuras but shuras should be called an "authoritative party" or "working group." If the group fails or splits into factions, parment should be stopped and a jirga called to solve the problem. If there is no unity in the shura it may be possible to work individually to solve individual problems. However, planning should not depend on unity of many tribes or different groups. This group also wanted to know why IRC is only planning to work in the four listed provinces since there has been suffering in all provinces and many groups are already planning work in these border provinces. Because IRC is the largest organization, it should have a leading role in the southwest where no relief work has been done. This group also felt that English is an important language and Peshawar education programs should focus on teacher training. They believed that Afghans should handle management and administration with expatriates as consultants, monitors and trainers. They also believed that assistance should be given to unregistered refugees and the poor inside Afghanistan, and not be limited to those with ration cards. The group found it difficult to reach a common conclusion on the type of assistance to be rendered and how it should be distributed. However, most felt that needed tools should be provided along with cash for work programs. They also felt that distribution might be best if it were done through the working group (shura).

Group 5 (chaired by Taj Mali) felt that shuras are important since they have traditionally solved complex problems, and they are the only option to implement projects and set priorities. IRC should employ people from the target area using expatriates for consultation and technical assistance. If the shura splits or does not follow policies, work should continue until it suffers from the division. The focus should be on rehabilitative work in the listed four provinces but it should also extend to Kabul (when possible), Kunar, Laghman and Ghazni Provinces. They felt that immediate repatriation is not practicable aue to mines, 
bombings and damage to irrigation systems. The first priority should be agriculture with preference also going to meeting food needs, mine awareness, health and education. There should be demonstration projects. They supported the idea of buying roof beams from returning refugees but felt that transport could be a problem. It was felt that cash should be given to refugees. They believed that aid should be extended to all persons in need and not limited to ration card holders. No distinction should be made between refugees, internally displaced and residents who stayed during the war. They also felt it important that appropriate technology be used in all IRC projects.

Tom Yates then gave a short closing speech in which he thanked all those present for participating in the conference. He pointed out that, in the same manner as shuras are forming inside Afghanistan, he wanted to form an advisory shura within IRC to assist in guiding IRC's policy making for the future. There was then time for questions and answers.

Finally, conference participants were asked to complete an evaluation form (Appendix $F$ ) on their reaction to the conference. In general, people were very positive. The highlight, according to many people, was the panel discussion on Friday morning since Afghans were able to ask questions of people to whom they would not normally have access. Afghan staff particularly enjoyed the small group discussions because, as they pointed out, it gave everyone a chance to talk and discuss things while the larger sessions did not allow for this. Many people also suggested that IRC sponsor similar but smaller conferences in the future to address particular needs, such as education (particularly higher education), management or agriculture. 
LIST OF APPENDICES

Appendix A - conference schedule distributed to all attendees and invitees.

Appendix B - list of IRC staff that attended (broken down by international and local staff) and guests that attended at least some of the conference.

Appendix C - the composition of the small groups that met to discuss issues (only IRC staff were listed since guests were free to choose the group attended or to move between the groups).

Appendix D - the outline of IRC's plans for the future and the format for the small group discussions. This was distributed to all persons attending the conference.

Appendix E - recorder's notes of the five small group discussions that were held on Thursday and Friday.

Appendix F - sample evaluation form. 
INTERNATIONAL RESCUE COMMITTEE

CONFERENCE SCHEDULE

Thursday, Feb. 23

Noon to 1:00: Banquet lunch at hotel for all attendees Crystal Ballroom $B$

1:00 to 2:00: Opening of conference by steve Segal who introduces Tom Yates - Crystal Ballroom B

Address by Tom Yates on IRC future plans for Pakistan and Afghanistan

Handout of 'T'om's address for future discussion

2:00 to 4:00 Break up into 5 groups of about 20 people each

Group Leaders: Dr. Anwar, Dr. Hassani, Eng. Aziz, Eng. Zahir, Taj Mali (in Conference Rooms 1 \& 2; Senator Room; and 2 groups in Crystal Ballroom $B$ Discussion of Tom's speech

$4: 00$ to $7: 30$ BREAK

$7: 30$

Banquet Dinner in Crystal Ballroom $B$

Speech by Anne Willem Bijleveld, UNHCR, regarding the UN's efforts to coordinate its approach to Afghanistan and their anticipated plans for Afghanistan

Afghan music after dinner and speech

Friday, February 24

$7: 30$ to $9: 30$ Breakfast in Sherezade Restaurant

10:00 to 11:00 Panel discussion in Crystal Ballroom B Topic: Comments and Reflections on the Citizen's Commission Report: Problems that the Refugees, Internally Displaced and Kabul will Encounter in Rebuilding Afghanistan

11:00 to 1:00 Break up into groups of 20 people (same group composition as previous day and same locations); same groups leaders

Discussion of morning speech

$1: 00$ to $3: 30$ Lunch (on your own) and Friday Prayers

3:30 to 4:30 Management Films shown for those interested Crystal Ballroom $B$ 
$4: 30$ to $5: 30$ Afternoon Tea in Crystal Ballroom B

Dinner (on your own)

$8: 00$

Evening Films on Afghanistan in Margala Room

Saturday, Feb. 25

$7: 30$ to $9: 30$ Breakfast in Sherezade Restaurant

10:00 to 12:00 General meeting on Recommendations for the Future Crystal Ballroom B Chaired by Tom Yates

Comments and discussion from the floor

12:00 Lunch with possibly another guest speaker Crystal Ballroom $B$

End of Conference 
International Staff

Tom Yates

Susan Yates

Steve Segal

Margaret Segal

Beth Kangas

Yogi Thami

Sheila Ludtjens

Jonathan Goodhand

Mike Barker

Megan McGrath

Cathy O'Brien

Valerie Cliff

Amina Amin

Jennifer Brokaw

Wendy Young

Crystal Ashley

Paul Morneault

Jonathan Rothenberg

Diana Stiles

Connie Miller

Charlotte Freihofer

Olga Zai

Mark Luce

Joy Juanvorachai

Theresa Molyneux

Mike Kerkelis

Sharon McDonnell

Owen Crowley

Andrew Infosino

Carolyn Henri

Janice Luce

Ka Wichaiboon

Bryce Isham

Paul Heinzen

Karen Seiner

Robb McCue

Toc Dunlop

Duke Miller

Gayle Ashton

Regine Mounier

Doug Barker

Martha McMillan

Peter Shultz

Robyn Bantel

Shon Campbell
Country Director

Administration

Deputy Director

Education

Education

Public Health

Health Education Resource Center (HERC)

Education

Public Administration

Education

HERC

Public Administration

Rural Assistance Project (RAP)

HERC

Public Administration

Education

Printing Press

Education

Education

Education

Administration

Public Administration

Administration

Administration

Maternal-Child Center (MCC)

Administration - Hangu

Rehabilitation Project for Afghanistan (RPA)

Self-Reliance

Medical

RPA

Education

Administration

MCC

RPA

Medical

Education

Education

Self-Reliance

Education

RPA

Medical

Education

Public Administration

Public Administration

Medical 


\begin{tabular}{|c|c|}
\hline $\begin{array}{l}\text { Abaul Lenir Reja } \\
\text { Mohammad Yousef }\end{array}$ & Self-Reliance/Construction \\
\hline Nasreen Madawa & MCC \\
\hline Qaiser Saleem & RAP \\
\hline Sayed Aga & RPA \\
\hline Mohammad Dhula & RPA \\
\hline Shawikat Zamani & Education \\
\hline Saeeda Imad & Public Health \\
\hline Aziz Osmani & Education \\
\hline Afifa.Wardak & $\mathrm{MCC}$ \\
\hline Ahmad Shah Nazir & RPA \\
\hline Dr. Muktiar Zaman & Medical \\
\hline M. Zaffer Sharifi & Education \\
\hline Hafsa Saddat & Education \\
\hline Farida Sulieman & Self-Reliance \\
\hline Dr. Anwar & RPA \\
\hline Noor Momanee & Public Health \\
\hline Awal Gul & RPA \\
\hline M. Aref Ahmadi & Self-Reliance \\
\hline Aziz Qureshi & Education \\
\hline Mohammad Sadiq & Self-Reliance \\
\hline Abdul Fattah & Self-Reliance \\
\hline Shaima Gulistani & Self-Reliance \\
\hline Ehsanullah Ehsan & Self-Reliance/Agriculture \\
\hline Dr. Wahed Hassani & Education \\
\hline Baqui Zai & Public Administration \\
\hline Sayed Modasir & Education \\
\hline Abdul Gafor & RPA \\
\hline Tajwar Kakar & Education \\
\hline Farida Kakar & Education \\
\hline Mohammad Sharif & Self-Reliance \\
\hline Munawar Sultana & Public Health \\
\hline Taj Mali & Public Administration \\
\hline Sher Haider & Administration \\
\hline M. Hashim Shahidi & Education \\
\hline Ghulam Sakhi & Education \\
\hline Syed Abdul Hadi & Administration \\
\hline Dastagir Fazalyar & Education \\
\hline Fazal Karim & Printing Press \\
\hline Abdul Ellah & Education \\
\hline Qadir Rasouli & Printing Press \\
\hline Gulam Q & Education \\
\hline Dr. Aks & HERC \\
\hline Janas & Administration \\
\hline Mossa & $\mathrm{RP}$ \\
\hline
\end{tabular}


Dr. Haider

Robert Saleon-Terras

Philippe Truze

Peter Rees

Ibrahim Sulieman

Mr. and Mrs. Robert Canfield

Mr. H.R. Seccombe

Mr. von Sponeck

Marisa Lino

Larry Crandall

Jorgen Abrahamsen

Martin Barber

Allen Jones

Bhim Udas

Ted Albers

Willem Homan
Swedish Committee

Medicins sans Frontieres

AVICEN

Afghanaid

Islamic Relief Agency

Fullbright Scholar

Australian Embassy

Director, UNDP, Islamabad, UN

Representative in Islamabad

Consellor for Refugee Affairs, U.S.

Embassy, Islamabad

USAID Representative, U.S. Embassy, Is lamabad

Charge d'Affaires, Danish Embassy

IJN Coordinator's Office

Director, World Food Programme,

Is lamabad

World Food Programme, Quetta ACBAR, Executive Coordinator ACBAR, Deputy 


\section{APPENDIX C}

$\begin{array}{ll}\text { GRouP } 1-\text { Conference Room 1 } & \text { Group } 3-\text { Senator Room } \\ \text { Abdul Zahir Reja-Group Leader } & \text { Dr. Anwar - Group Leader } \\ \text { Beth Kangas - Recorder } & \text { Charlotte Freihofer - Recorder } \\ \text { Mohammad Yousef } & \text { Olga Zai } \\ \text { Yogi Thami } & \text { Mark Luce } \\ \text { Shiela Ludtjens } & \text { Joy Juanvorachai } \\ \text { Nasreen Madawa } & \text { Theresa Molyneux } \\ \text { John O'Brien } & \text { Mike Kerkelis } \\ \text { Jonathan Goodhand } & \text { Sharon McDonnell } \\ \text { Mike Barker } & \text { Owen Crowley } \\ \text { Megan McGrath } & \text { Noor Momanee } \\ \text { Qaiser Saleem } & \text { Awal Gul } \\ \text { Cathy O'Brien } & \text { Mohammed Aref Ahmadi } \\ \text { Sayed Aqa } & \text { Aziz Qureshi } \\ \text { Dr. Nizam } & \text { Mohammad Sadiq } \\ \text { Mohammad Dhula } & \text { Abdul Fattah } \\ \text { Shawikat Zamani } & \text { Shaima Gulistani } \\ \text { Saeeda Imad } & \text { Ehsanullah Ehsan } \\ \text { Valerie Cliff } & \text { Andrew Infosino } \\ & \text { Group 4 - Crystal Ballroom B } \\ \text { GRoup 2 - Conference Room 2 } & \text { Dr. Hassani - Group Leader } \\ \text { Aziz Osmani - Group Leader } & \text { Carolyn Henri - Recorder } \\ \text { Amina Amin- Recorder } & \text { Baqui Zai } \\ \text { Bobbi Thami } & \text { Janice Luce } \\ \text { Jennifer Brokaw } & \text { Ka Wichaiboon } \\ \text { Wendy Young } & \text { Bryce Isham } \\ \text { Afifa Wardak } & \text { Sayed Modasir } \\ \text { Crystal Ashley } & \text { Paul Heinzen } \\ \text { Paul Morneault } & \text { Karen Seiner } \\ \text { Jonathan Rothenberg } & \text { Ted Albers } \\ \text { Ahmad Shah Nazir } & \text { Robb McCue } \\ \text { Dr. Muktiar Zaman } & \text { Toc Dunlop } \\ \text { Dr. Mohammad Qayyum } & \text { Abdul Gafor } \\ \text { Mohammad Zaffer Sharifi } & \text { Dr. Dost } \\ \text { Hafsa Saddat } & \text { Tajwar Kakar } \\ \text { Diana Stiles } & \text { Farida Kakar } \\ \text { Faride Suleiman } & \text { Mohammad Sharif } \\ \text { Connie Miller } & \text { Munawar Sultana } \\ & \text { Duke Miller } \\ & \end{array}$


GROUP 5 - Crystal Ballroom B

Taj Mali - Group Leader

Gayle Ashton - Recorder

Dastagir Fazalyar

Sher Haider

Regine Mounier

Fazal Karim

Martha McMillen

M. Hashim Shahidi

Abdul Ellah

Ghulam Sakhi

Doug Barker

Syed Abdul Hadi

Shon Campbell

Peter Shultz

Qadir Rasouli

Robyn Bantel

Gulam Qadir

Richard Quinby

Dr. Akseer

Janus Khan 


\section{APPENDIX D}

OUTLINE OF IRC'S PLANS FOR THE FUTURE

1. The IRC will continue its programs in Pakistan, slowly decreasing them as refugees return.

2. The IRC will help in the rehabilitation of Afghanistan and repatriation of refugees. The IRC will focus its efforts on rehabilitation in Paktia/Paktika, Logar and Ningarhar. Some programs, especially in training and education, will remain in Pakistan until conditions become stable in Afghanistan. These same programs could transfer to other areas in Afghanistan. The IRC's work in Afghanistan will be temporary. As soon as possible, programs will be completed or turned over to government or other Afghan organizations.

3. The IRC will coordinate its efforts with the Government of Pakistan, the Reconstruction Authority for Afghanistan, and other organizations.

PILOT PROGRAM FOR PARTIAL REPATRIATION OF REFUGEES FROM HANGUTHAL AREA TO PAKTIA/PAKTIKA, LOGAR AND NINGARHAR

1. Politically stable areas in those provinces will first be helped.

2. Repair and rehabilitation of agricultural, water supply, and other infrastructures will be the first priority.

3. Assistance will be given for food supply and storage, and repair of roads.

4. Training in agriculture, administration, construction and mine awareness will be given.

5. Assistance to health and medical services will be given.

6. Assistance to community schools and assistance with teacher training will be provided.

7. Assistance will be provided through local councils or shuras.

8. Direct assistance will not be provided for rebuilding houses. However, some money might be given to returning refugees who bring roof beams in order to help them with costs of transport. 
Project Implementation

1. The IRC will only provide aid when requests from local shurac are received.

2. Each shura must provide one or more representatives to work with IRC. They will receive training when necessary.

3. The provision of commodities will be done in cooperation with U.N. agencies and the local shuras.

Project Administration

Community Workers: These are persons chosen by the shura to implement projects proposed by the local shura and approved by IRC. They are not IRC employees. If the shura decides to pay them for work performed, they will be paid directly by the shura from shura funds. (The shura may obtain funds from IRC - in installments - upon IRC approval of its project proposals.)

Community Liaisons: These are IRC staff members who are responsible for one or two districts. They assist the community in preparing proposals and administering, reporting on and monitoring projects. They communicate community concerns to IRC and IRC policies to the community.

Project officer: These are IRC staff members who supervise Community Liaisons. Each one is responsible for one province. This person arranges for technical assistance as needed.

Technical Consultants: These are IRC staff members who are specialists in certain technical fields, such as civil engineering, agriculture, health or education. They advise in selection and planning for projects. They will assist in technical aspects of project implementation. They can also train community workers when necessary.

Administrative staff: These are IRC employees who work in IRC's administrative offices in Pakistan. They keep data records, reports, and files. They procure materials, do planning and evaluation, and coordinate with other IRC projects and other organizations. 
(Thursday, 2:00 to 4:00 and Friday, 11:00 to 1:00)

1. IRC staff should find their names on the lists provided in the welcome packet and go to the room assigned. Guests are welcome to attend any group discussion they wish.

2. A Group Leader will lead the discussion. When you want to speak, please raise your hand and be recognized by him.

3. A recorder will take notes of the meeting.

4. Feel free to ask for translations or clarifications if you don't understand something.

Thursday, 2:00 to 4:00

DISCUSSION OF IRC FUTURE PLANS FOR PAKISTAN AND AFGHANISTAN

Questions for Discussion. Please discuss each set of questions for 20 minutes.

Since IRC plans to work first in Paktia/Paktika, discuss the plans for these two provinces first.

1. What do you think about providing assistance through village councils (shụras)?

- What are the positive and negative aspects of this?

- What should IRC do to make working through shuras a success?

- What should IRC not do to make working through shuras a success?

- What should IRC do if

a: the shura does not complete its work correctly?

$\mathrm{b}$ : tribal or other conflicts between areas develop?

c: the shura splits into opposing groups?

d: an area doesn't have a council that represents its people?

2. What do you think about IRC focusing its efforts on rehabilitation in Paktia, Paktika, Logar and Ningarhar? What other provinces, if any, would you suggest and why?

3. Will the efforts described in this plan help refugees to quickly resettle in Afghanistan?

- Which parts of this plan are the best?

- Which parts are not important or will not work well?

- What suggestions do you have for improving the plan?

- What are the priorities of work that should be done for rehabilitation and repatriation? 
4. Until the first crops can be harvested, returning refugees will need food or money to buy food. What do you think about:

a. Giving refugees money when they bring their roof beams across the border (Beams will be marked.)

b. Giving Afghans (whether refugees or not) cash for work?

c. Giving food for free to villagers?

d. Giving food to villagers in return for working on communal projects?

e. Reregistering refugees, marking the registration cards (so they can't be forged), and giving them money when they return their marked registration cards? (Cash received would be used by refugees to buy supplies when they return home.)

$f$. Other ideas for giving food or money for food? 


\section{APPENDIX E}

IRC Conference

Group 1

Group Leader - Abdul Zahir Reja

Recorder - Beth Kangas

During our discussion groups on 'I'hursday and Friday, we discussed the following topics:

-- "shuras", including which shuras IRC should work with, how to monitor the shuras, and how to train foremen assigned by the shuras.

-- the location of IRC's work inside Afghanistan.

-- how to pay for work done inside Afghanistan, including cash for work, adjusting for inflation, and food for work.

-- how to generate income and food for refugees returning to Afghanistan, including a payment for transporting beams, Project Marketplace, ration cards, and food distribution.

-- the Seven-Party Alliance and a future government.

-- mine awareness, including the lack of work being done by the UN and Aga Khan and the amount of time necessary when working with them, and a visit by Martin Barber who explained the criteria used by the UN when considering the acceptance of mine clearance materials, what IRC can do in the field of mine awareness.

Recommendations are as follows:

- IRC should work with shuras in politically stable areas where there is no fighting. IRC should not have a general policy of working only with district shuras, but should be open to different make-ups of shuras, thereby maintaining a case by case flexibility. Changing the structure of present shuras or imposing the boundaries of shuras will not lead to successful cooperation; instead IRC should work through existing shuras, whether they be local or district shuras. The authenticity of each shura needs to be verified to ensure that it represents the opinions of the whole community.

-- If a split should occur within the shura during a rehabilitation project, a committee of representatives from the different sides should be formed in order to complete the project.

-- The authority of shuras will probably change to a government authority when a desirable government comes into power. 
-- Irrigation canals, water supplies, clinics and schools were recommended areas to work in. Priorities in rehabilitation, though, should be decided by the community, not by a standardized list. Prioritizing case by case in each village would ensure that what already exists in the community would not be duplicated unnecessarily.

-- As a basis of what kinds of projects to accept, it should be remembered that in Afghanistan, IRC is involved in rehabilitation, not in development.

-- To supervise projects and ensure proper use of funds, money should be paid in installments. Work should be started on a small scale. Technical consultants should have power in quality control. If work is not completed successfully during the first installment of funds, then an IRC team could be sent in to work with the local groups during the second installment of funds.

-- In the "Outline of IRC's Plans for the Future," under "Project Administration", the word "assist" should be changed to "control" to read "[Technical Consultants] will control technical aspects of project implementation."

- People could be trained in small-scale technical skills to assist in rehabilitation projects.

-- Regarding salaries, it is recommended that food and a minimal amount of money should be given for work. The community should be made aware through its shura that they are working for themselves and their community, not for a profit. Food should not be given out, the only possible exception being to widows and handicapped people who may not be able to work for food.

-- As a way of planning how to work in various communities in Afghanistan and assisting in the return of the refugees, IRC could give a schedule of which villages or districts it would be working in at which time. Then if refugees decided to go back before the scheduled time, they would be responsible for themselves. Distribution of food should continue in Pakistan to ensure a slow return of refugees.

-- Regarding unregistered people, who are the poorest of the poor, some Community Health workers are willing to decide which refugees in IRC camps are unregistered or poor. In other situations, the community should somehow decide which members are the poorest, and thereby the most needing of assistance.

-- In order to accelerate the process involved in receiving approval for mine awareness materials, meetings should be held with groups involved in mine awareness. Because of their experience, NGOs should play a big role in mine awareness. 


MINUTES OF MEETING OF THE
CITIZENS COMMISSION CONFERENCE

HOST : INTERNATIONAL RESCUE COMMITTEE

VENUE : HOLIDAY INN, ISLAMABAD

DATE : Feb $23-25,1989$

ATTENDANCE: Group 2 - 1st \& 2nd Day Discussion

Engr. Aziz Osmani - Group Leader

Bobbi Thami

Jennifer Brokaw

Wendy Young

Crystal Ashley

Afifa Wardak

Paul Mourneault

Jonathan Rothenberg

Ahmad Shah Nazir
Dr. Mohammad Qayyum

Mohammad Zaffer Sharifi

Hafsa Saddat

Farida Suleiman

Diana Stiles

Connie Miller

Rita Canfield - Guest

Dr. Mukhtiar Zaman

Recorder : Amina M. Amin

INTRODUCTION :

This conference was organized in order to discuss mainly IRC's future plans for the rehabilitation of Afghanistan and repatriation of refugees. Focusing first on the Provinces of Paktia/Paktika, Ningarhar and Logar.

The discussion began with Engr. Aziz introducing himself and urging the other members to do the same. He then showed the different charts which he had prepared, namely:
a. the different areas in Paktika, Paktia, Ningarhar \& Logar,
b. the corresponding number of refugees located at the Hangu-Thal camps, the number of refugees who can return to their villages, and
c. the relationship between the two administrative structures: IRC and the Designated Shura Administration (DSA).

The first question brought up was "Why were these provinces chosen?" It was pointed out that there are approximately 198,000 refugees in the Hangu-Thal camps and that $98 \%$ of these people come from these areas. It was further explained that shuras are composed of town elders, mullahs \& commanders, what their duties to the people were and their relationship with the CLO (Community Liaison Offices) which is IRC. 
Duties of the Shura:

I. To acknowledge, assess \& make recommendations for the betterment of their district/village keeping in mind that these are in the interest of the people and that they would directly benefit from it.

II. To submit these as formal proposals to the CLO for approval and subsequent funding. IRC and the shura would have to sign an agreement.

III. To act as the administrative structure through which these proposals will be implemented.

One of the many conditions that would be attached to these 'agreements' is that funds will be on installment basis only. Subsequent payments will be made upon successful completion of preceding stages of the project. If, at any time during the execution of a proposal, the CLO has evidence regarding: 1) funds being misappropriated; 2) the project is not going according to plan; or 3) for any other justified reason, then in such cases the funds will be stopped forthwith and no further payments will be made to the shuras.

Monitoring of proposals has to be done by the shuras and reported to IRC. Shuras will be overall in-charge of their own projects.

The following are relevant responses to questions raised to the above-cited introductory statement.

1. What do you think about providing assistance through shuras?

A shura is a body that arises out of necessity. Shuras have the voice of the people and their support. There are different types of shuras: provincial, district, tribal, and those based on parties. Provincial shuras are only successful if the areas are not under communists.

2. Has IRC set conditions or criteria for working with a certain shura?

IRC has to work with shuras who show cooperation and organization among themselves. It is better to go with the different 'waves' of shuras and not to create 'new waves'.

3. What guarantee has IRC in that there won't be a rift within the shura that would prevent the implementation of the project? What about difference in opinion between shuras? 
There really is no guarantee. Before, shuras were there to handle small community problems, now they have a much more immense job to tackle, but can they handle them? Also there will be pressure from donors to evaluate how shuras are implementing their projects.

We would just have to rely on the hope that their urgent needs and interests for the common good of all, will bind them together. And it is this hope and trust that will safeguard IRC's and the shuras' relationship. It is comforting enough to know that shuras from different districts have already combined in order to assess their people's needs and to present these as proposals to IRC. The time spent and the effort taken to accomplish this and to travel all the way here (to IRC) shows that they are sincere in their struggles and that they are determined to really accomplish feats on their own with the CLO's support.

4. What about women? What will happen to widows? should not women be included in the shuras too? Will the shuras work for the women's and children's interest and welfare too?

A sensitive problem is questioned here, but it is practical and should be bridged. We think women should have a say or a part in any shura. Women have fought side by side with men in battlefields, why not share in this too?

5. But will the men allow the women to participate in the shura? Example is a woman who was requested to do something for the community and in reply she said, "Let me first ask my husband's/father's, or uncle's permission." Is this the prevalent condition for women?

Widows, since they do not have any husband to answer to, should be able to serve their community in some way. The men, in general, should remember that Afghanistan is in a state of war and should realize the difficulties and needs this war has brought on all of them. But it will depend on local attitudes and cultures in each area.

In our opinion, it is a time to work together to reach a common goal, and that is to rebuild Afghanistan. Prejudices and taboos that do not serve any good, should be forgotten at this point and people should get on with more urgent issues like medical care, health, child nutrition, education of women and children, reconstruction and rehabilitation. While men are busy in reconstruction, irrigation repairs, agricultural projects, etc., women can be busy in health care, education, medical assistance, mother and child centers or wherever their services can be rendered. 
6. On the issue of de-mining:

People need a sense of security in order to go back and start rebuilding their homes and livelihood. And if mines are still present in any given area, then repatriation is quite out of the question. Mine awareness should be integrated in all the programs of IRC, wherever feasible. In education alone, the structure itself will help mine awareness reach the womenfolk and the children. Medical programs should include mine awareness. Construction too can have its share of giving out information on this issue. There are a lot of 'channels' through which refugees can be made aware of mines.

Some of the questions brought up, and to which there were a few answers or which were not fully answered were:

1. Are there any alternatives aside from the shura?

We think not, since the shura is the only active governing 'body' representing the people of Afghanistan and wherein IRC has taken an attempt to work with Afghans. Although some areas still do not have shuras, the future alone will improve this condition.

2. What if materials are given instead of money?

There will be too much trouble in their transport. Again this will enhance 'parental support' which IRC wants to depart from.

3. What if some shuras play a dominant role and others a lesser role?

It is a just a matter of influence and is due more or less to the number of members of certain shuras.

4. Do you think shuras will have the ability to sustain whatever projects they have started, like education, medical, community restoration, etc?

Shuras should develop projects where people are really interested so that it has their support and people would really work hard for the project to succeed. Thought should be given to developing better organizations to minimize dependency on the CLO.

5. Are we going to run into problems internally? Would people agree to work in areas where they do not originate from? would there be a difference in opinions? 
We should train engineers, doctors, teachers, etc. to work in different areas, thereby enhancing communication and cooperation. We do not foresee any difficulties in this respect since everyone has the same needs and goals.

6. What happens if refugees refuse to go back? Will refugees go back to liberated areas only? What if refugees have to go to areas where they do not come from, their place of origin not being liberated?

Let Afghans take things the way they are, support them when they do move, but do not force them.

7. Is it necessary for Kabul to fall before refugees would go back? Will it take time?

In the refugees' opinion, the fall of Kabul and the subsequent political stability of Afghanistan will be considered before any full repatriation can be accomplished. Also the main issue before any of this will be de-mining.

8. What factors would prevent refugees from returning?

Basically, if an area isn't liberated, isn't stable or secure enough, and living conditions are not good, then these would probably prevent refugees from returning.

RECOMMENDATIONS FOR FUTURE REHABILITATION \& REPATRIATION:

1. We see the Shuras (DSA) as a proper channel through which assistance could be provided for the people. Although there should be a written agreement between IRC and the shura regarding funds and its disbursement. IRC will have the authority to stop funding in cases of misappropriation and other valid reasons IRC might have.

2. IRC should announce from the very beginning that its work in Afghanistan. will be temporary. As soon as possible, programs will be handed over to the DSA and that one day, they will be cverall in-charge. As IRC support diminishes, the DSA's or shuras' responsibilities will increase.

3. We agree on the point that women should be encouraged to participate in shuras and to have a voice in any of their decisions. They should be given a chance to work for the good of the community. Only shuras who can prove they represent the whole community, including women, will be granted contracts. 
4. Mine awareness and first aid should be incorporated in all the programs of IRC. Include in education at all levels, as well as in health programs. Slides, handouts, pamphlets, \& scheduled training sessions in both of these subjects should be available to all.

5. English should be taught as a jecond language. The way for any country to develor is to have a good knowledge of English. Advanced technology, medicine, engineering, electronics, etc. are ali written in the English language and it is an international language. The Afghans need to feel that they are not cut off from the rest of the world because of this deficiency

6. Sociology is also an important subject we feel necessary in our training programs. Field workers should study the Afghan sociology before departing for those provinces. Also to take into consideration that the large number of widows and orphans have unbalanced the sociological structure of Afghanistan and solutions have to be formulated.



Group members were quite optimistic about future plans for Afghanistan and her people in particular, although there were a few pessimistic remarks made at some points in the discussions.

Although time wasn't sufficient to cover the other recommended topics, all in all, it proved to be a very active and absorbing group discussion. 
INTERNATIONAL RESCUE COMMITTEE

Citizens commission Conference

Islamabad, Feb. 23-25, 1989

NOTES -- Group 3

Dr. Anwar/Team Leader

Charlotte Freihofer/Recorder.

Sharon McDonnell

Olga Zai

Mark Luce

Joy Juanvorachai

Theresa Molyneux

Owen Crowley

Ehsanullah Ehsan

Noor Mornanee

Awal Gul

Mohammad Aref Ahmadi

Aziz Qureshi

Mohanmad Sadiq

Shaima Gulistani

Abdul Fattah

Guests:

Dr. Canfield, Afghan anthropologist

Allen Jones, WFP

Martin Barber, UN Coordinator's office

Peter Rees, AFGHANAID

Mr. Masoody, former IRC staff

Bushra Gohar, former IRC staft

The following is a rough sketch of dialogue which took place over two group meetings. In general, participants tended to delve into a particular subject from a variety of viewpoints (ie. Project Marketplace); consequently many questions were not explored fully due to time limitations.

Assistance Through Shuras

-As the situation in our country is unclear, with no acting government, it is a good idea to work through shuras. Unlike American or European societies we Afghans have a tribal system.

-Shuras consist of elders, mullahs, commanders; they are tribal gatherings with an elder, called à "Inalik," as the controlling force.

-Directing a project to a community shura will make the people involved more responsible.

-You need a commander's permission to work with a local shura. Most cross-border agricultural agencies (AFGHANAID) work this way, with trained Afghan field teams of 2-3 people who act as monitors.

-The weak link in this plan is the liasion officer/community worker. They should work closely with the shura to determine if the IRC's goals are being achieved. 
-With regard to districts or other areas in Afghanistan-different areas are going to develop differently

-IRC should maximize its training programs for Afghans. The work through community shuras could be made easier by having IRC people involved in a direct way. This would help in relationship to the shura.

-If a project fails due to lack of administration, then improve the supervision of the project. If communities have a problem let them solve it themselves; IRC should be a third party (i.e., non-aligned).

-Some provinces don't have shuras (Logar) but there will be commanders in place as a power source. How these groups will. work in regard to humanitarian assistance no one knows.

-You have to work to learn by your mistakes. Assistance through shuras is a good plan at this time but IRC should be flexible and should anticipate future difficulties in administrating such assistance.

Project Marketplace

-The focus of Project Marketplace is food distribution through traders. Refugees can exchange their ration cards for cash, which will give them buying power to obtain seed, fertilizer and food. Distribution of commodities will be implemented by UNILOG, the logistical arm of the U.N.

-NGO's have repeatedly been asking for immediate agricultural assistance through the FAO and other UN bodies; furthermore it has been established through ACBAR that agricultural rehabilitation programs take precedence over other kinds of assistance. Why hasn't the UN responded more quickly? The spring planting has already passed and we will miss the fall planting too if something is not done immediately.

-The FAO has already sown 2,000 tons of wheat seed in Afghanistan for the spring season. However, there is a problem with availability of spring wheat seed in paxistan; the GOP says they cannot furnish any. The top priority for the program is to get funds for the purchase of seed and fertilizer to be used in time for the fall planting. Agricultural projects are being funded through UNHCR; hopefully additional networks will be established by the fall sowing season.

-Will the traders hoard the goods or manipulate prices? We are afraid of the black market. Now government prices are $3-5$ times the true commodity price. If, for example, an independert $\lambda_{\text {f }}$ ghan: fertilizer company was established the people would rot have o black market. 
- What about the soviet pledge for commodity assistance? Can you tell us what has been happening on this issue?

-Some progress has been made in Geneva regarding the soviet bilateral pledge through the U.N. Everyone is discussing the subjects of fuel, seed, fertilizer... any new (Afghan) government will have to consider this offer quite seriously.

-The U.N. Coordinator's office has taken a "hands-off" approach to Project Marketplace. One of the interesting elements is the selling of cash crops and ration cards. What will be done about the unregistered refugees?

-No one knows how many unregistered refugees there are in Pakistan. They are working in the bazaars or communities for lower wages than Pakistani laborers (25-30 rupees a day) and have been able to survive in this way. But there should be equal distribution of ration cards to all refugees in Pakistan in order for Project Marketplace to work.

-The commodities may be ambushed en route to Afghan villages and towns. The U.N. should consider the logistical difficulties it may encounter in this program.

-Emphasis should be placed on financing food production so that the refugees can return home. The food for work plan is a far less devisive situation than paying for someone's ration card. Leave ration cards alone. 
Is lamabad Conference

Group 4

Group Lgader - Dr. Hassani

Recorder - Carolyn Henri

The initial discussion was the definition of a shura. Mr. Ghafoori said that the concept of a shura is recent and a product of the war. It sprang from the need to make decisions but the shura itself is not interested in specific subjects. Individuals themselves want to run things. Dr. Haider said it is difficult to form shuras in paktia because of its tribal structure.

There is the problem of working with one and not another shura which would create jealousies and difficulties for IRC. The people forming the shura must be trusted and respected by all the people. There are some shuras that presently implement projects, especially the one under Commander Mahsood. The Swedish Committee is implementing projects through this shura, along with three other NGOs. Also, SCF is using a small shura to do irrigation repairs in Kandahar.

The implementation of projects through shuras must depend on the situation. Sometimes it is better to work with the commanders rather than the shura. "Council" rather than "shura" should be the term used.

The working group in the area which has influence and power should be the name for the shura.

Smaller cormanders will fall in line with bigger commanders after repatriation since they won't have any other choice from the point of view of power. The divisions and tensions in Afghanistan are tribal, political party and religious. IRC's decisions about interactions with the shura will need to be coordinated with other NGOs.

What should Afghan and expatriate involvement in projects be? Afghan administrators are prone to many political, social and tribal pressures. In this sense, westerners are more unbiased. Expatriates should be observers and monitors, and not implementing programs. It is good for expatriates to be advisors and trainers but $n$ fghans should be administrators.

Teaching English is not a priority even though all Afghans want to learn English. There are other priorities which are more important.

What about comnodities? Everyone should be given tools, rather than cash. There should be business incentive programs. The local authority could buy tools and distribute them to skilled people. This, instead of cash for work, should be used. 
What about the division of Afghanistan between NGOs and UN agencies? The Swedish Committee is willing to share information on its medical programs with IRC. ACBAR is trying to find out which areas aren't covered and then see what can be done in those regions. They will also try to find out what the conditions are in those areas and why there is no aid there. NGOs are limited by their small budgets.

Business incentive programs should be done directly with businessmen, but the shura should pick the businesses. 
Is lamabad Conference

Group 5

Taj Mali/Group Leader

Gayle Ashton/Recorder

Each point generally represents an individual viewpoint.

Paktia/Paktika - THURSDAY DISCUSSION

1. Assistance through shuras

- problems with district shuras

a. differences among tribal groups

b. the representative may be accused of favoring his own group

c. what happens after IRC leaves?

- Shura membership size. Is there a minimum size?

- Shura definition (according to Steve Segal)

A shura is any defined area agreed to, it could be a tribal shura, a commander shura, as long as there are politically stable conditions and support from the community. A shura can be formed from whatever power represents the people in an area.

- QUESTION? How to identify shuras that really represent the communities? Before the war, tribal elders decided local affairs. Not it's possible that commanders may have the role of making shuras.

- QUESTION? Did shuras traditionally make decisions about schools, water systems, etc.?

- Based on the Ghazni experience, commander shuras would not be representative of the entire community.

- QUESTION? In the past, how was it known that a shura was supported by the people? ANSWER. Elders were automatically respected.

- Commanders are also like elders, in that they are the delegates of the people now.

- Help through a shura should be the first aim of IRC, but IRC should help an entire district at one time so that all the people will be satisfied.

- QUESTION? There are so many parties, so many comma ders, how can IRC choose? 
- QUESTION? What are the responsibilities of shuras IRC selects? Many members will be illiterate.

- QUESTION? What will happen if the shura does poor work? ANSWERS: cut their money off, or just look on it as a learning experience, or IRC should pay a salary to someone who will be responsible for the job.

- IRC should ask the people what they want and later establish an office to complete the job so the money doesn't go into someone's pocket.

- QUESTION? If the shura splits... ANSWERS: In the beginning designate one person to solve conflicts or, if they don't make any problems for IRC it doesn't matter if the shura splits.

2. Focus on Provinces

- ACBAR won't divide Afghanistan among the agencies, but it may happen this way practically.

- Does IRC go first where infrastructure is more developed (Logar) or build from scratch in areas of greatest need?

- Kunar, Laghman and part of Kabul connected to Ningarhar should be considered for IRC assistance also.

- Will IRC increase tensions in an area by supporting various types of shuras?

- IRC should contact religious leaders in areas.

- Is there any other option but shuras? (Tom says no)

- What about the possibility of working through a commander?

- In Paktia, the shura is the best means because people are mostly from one tribe. It may be more difficult to work through shuras in other areas.

- In working with shuras, IRC should develop a group of contact people the shuras are familiar with, not just one person, so if someone leaves and goes back to the states, there is stilla familiar contact for the shura.

- Co-ordinate with other agencies.

- Shura representatives will get training with IRC to carry out projects: a) immediate training to use a manual and b) long-term training 
- If IRC tells an area what project to do, people may say IRC is trying to impose ideas, such as Christianity. Therefore, the suggestion, however sketchy in its initial form, must come from the shura.

- It doesn't matter who is a shura member as long as it is formed by the community, not IRC.

- QUESTION? What if IRC wants a Traditional Birth Attendant Program but the shura won't allow it?

- Select honest people and youths as well as elders. Find out who is popular in an area.

- Give priorities to areas where refugees IRC has helped are from.

- IRC will give different types of aid to different areas.

- Some districts of Ningarhar and Kabul should be included.

- IRC could go easily to Ghazni - it's accessible and free.

- People from other provinces are also familiar with IRC.

CONSENSUS: add Ghazni, Kunar, Laghman Provinces.

3. Resettlement

- Is it already too late for people to go back this year? They need: security, time to rebuild houses, end of the Kabul regime, mine clearance, FOOD, planting, seeds and irrigation.

- How quickly can they resettle? One month, one year?

The best part of this idea: Shuras involve Afghans.

Aspects that aren't so good?

Some programs aren't working quickly enough, seeds are not being delivered, programs are not practical enough, when will karezes be cleaned, in 3 weeks it will be too late.

Does this mean resettlement will occur in 1990?

- Do demonstration projects now, such as delivery of seeds, or cleaning of a karez.

- What about delivering oxen, horses, tractors? Start Now. 
4. What about giving food or money to refugees?

- Establish food storage and distribution points.

- Give money to refugees, not beams.

- Use systems from the past. After WWII, ration cards were used that could be added to with work. And for example, in Kampuchean camps, only women get ration cards.

\section{FRIDAY DISCUSSION}

First we made a list of points that interested the group:

- political aspects of reconstruction

- ways to put an end to the war

- political vs. economic refugees. Will Afghan refugee status in Pakistan change after Soviet withdrawal? And if so, who will support them?

- budget

- training for mine clearance/mine awareness

- What will be the effect of the Alliance government?

- higher education

- aid to the western and northern areas of Afghanistan. Who is planning this?

- IRC should extend aid to more provinces

a. The end of the war.

- We have no control over this.

- Because we don't, we should train people in transferable skills, such as medical technicians.

- Train technicians who in turn can train other Afghans

- What about internal refugees?

- We can't ask UNHCR to provide assistance to non-refugees, but we can make an arrangement with other agencies to do that.

- Divide Afghans into various categories of assistance.

- The Alliance should ask the NGOs to form an umbrella organization to portion out areas where they will work.

?? Organizations such as Farouk Azam, ACBAR, Ministry of Reconstruction, or anarchy as usual.

- The Coordinators office isn't giving direction, people are asking ACBAR to do more.

- Before the war the NGOs in Afghanistan were controlled by the Afghan government. 
- One problem with mine training is that the Pakistani Army ultimately chooses who learns the techniques.

The Islamabad Shura

- Shuras should seek help.from the Pakistan government.

- To what extent is the shura in Islamabad aware of district needs inside?

- If commanders don't accept this government, they will form their own government inside.

Beams

- It's an idea at a time when there's a shortage of ideas.

- Don't transport them from Pakistan.

- Train people inside to make concrete-reinforced beams.

- Exchange their work for food.

- Use only in appropriate areas.

- Use appropriate technology, e.g., shiva ram blocks.

- Houses in Nasir Bagh are built without beams.

- Dome houses are okay in non-earthquake areas.

- Contact commanders for their technician needs.

- Can beams be made that don't need steel imported from the outside?

- Traditional houses of Kandahar have a roof of bricks, built without beams.

- Beams are needed for a two-story house for big families.

- Consider culture as well as technology. 


\section{APPENDIX F \\ IRC \\ CITIZENS COMMISSION CONFERENCE \\ EVALUATION}

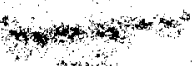

Please use the back if you don't have room under each question.)

1. What did you think about:

a. Tom and steve's presentation on Thursday?

b. The smali group discussions?

c. Mr. Anne Willem Bijleveld's speech on Thursday night?

d. The panel discussion on Friday morning?

e. The films, the free time and the extra activities?

f. the summary on saturday?

2. How was the organization of the conference?

3. In the future, what other activities would you like to participate in to help plan for reconstruction or to improve the management of IRC?

4. Any other comments? 